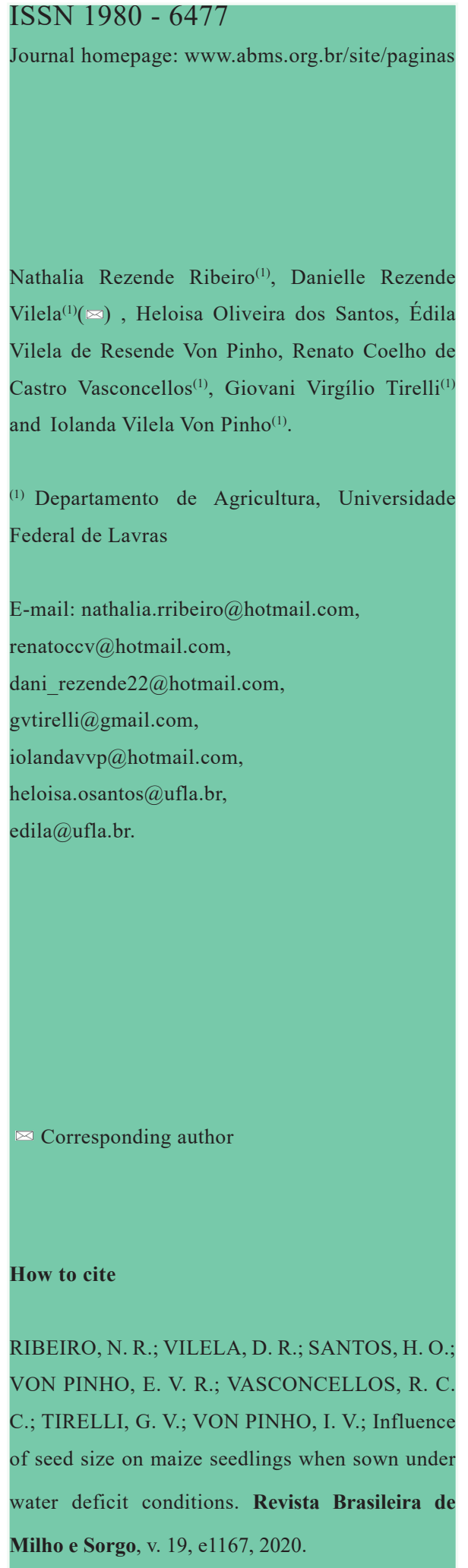

\section{INFLUENCE OF SEED SIZE ON MAIZE SEEDLINGS WHEN SOWN UNDER WATER DEFICIT CONDITIONS}

\begin{abstract}
Seed size may affect the initial development of seedlings, especially under adverse conditions such as water deficit. The objective of this study was to characterize the influence of seed size on traits presented by maize seedlings under contrasting conditions of water availability. The experiment was conducted with a tolerant line (L91), a non-tolerant line (L57), and with the $\mathrm{F}_{2}$ resulting from the cross between those lines. The seeds were classified with the use of round-hole sieves and those retained on sieves of sizes 22,20 and 18/64" were used. The seeds were sown in trays containing sand and, in order to simulate water deficit, the water retention capacity was adjusted to $10 \%$ (stress) and $70 \%$ (control). Four replications were used, with 25 seeds per treatment, which were stored in a growth chamber at $25^{\circ} \mathrm{C}$ for 7 days. Then the number of seminal roots, length of root and shoot, and their weights (fresh, dry and total) were evaluated. The seed size directly influences the development of maize seedlings, when subjected to water restriction, regardless of whether they are lines or F2. In this case, the larger-size sieves (22 and 20) were superior when compared with the size 18. In the early stages, the L57 was more tolerant to water restriction when compared with L91.
\end{abstract}

Keywords: Zea mays, abiotic stress, sieve, initial growth.

\section{INFLUÊNCIA DO TAMANHO DA SEMENTE EM PLÂNTULAS DE MILHO SEMEADAS SOB CONDIÇÕES DE DÉFICIT HÍDRICO}

\begin{abstract}
Resumo - O tamanho das sementes pode afetar o desenvolvimento inicial da plântula, principalmente em condições adversas, como é o caso do déficit hídrico. Objetivou-se caracterizar a influência do tamanho das sementes sobre as características de plântulas de milho em condições contrastantes de disponibilidade de água. O experimento foi conduzido com uma linhagem tolerante (L91) e uma não tolerante (L57) e com a F2 resultante do cruzamento dessas linhagens. As sementes foram classificadas em peneiras de crivos circulares e foram utilizadas as retidas nas peneiras de tamanho 22, 20 e 18/64". As sementes foram semeadas em bandejas contendo areia e para simular o déficit hídrico ajustou-se a capacidade de retenção de água para 10\% (estresse) e 70\% (controle). Foram utilizadas quatro repetições de 25 sementes por tratamento, acondicionadas em câmara de crescimento a 25 ${ }^{\circ} \mathrm{C}$ por 7 dias e avaliados o número de raízes seminais, comprimento de raiz e de parte aérea e seus pesos (fresco, seco e total). O tamanho da semente influencia diretamente no desenvolvimento das plântulas de milho, independentemente de ser linhagem ou $\mathrm{F}_{2}$, quando submetidas à condição de restrição hídrica. Neste caso, as peneiras de maiores tamanhos (22 e a 20) foram superiores quando comparada com a de tamanho 18. Nos estágios iniciais a L57 foi mais tolerante à restrição hídrica, quando comparada com a L91.
\end{abstract}

Palavras-chave: Zea mays, estresse abiótico, peneira, crescimento inicial. 
Agriculture is an activity that is highly dependent on biotic and abiotic factors, which may significantly influence the plant development. Among them, the water deficit, resulting from low water availability, is one of the factors that most affect the crops, since it directly impacts the metabolism, the plant growth and, consequently, the production (Rao \& Chaitanya, 2016).

The grain production has great economic importance in the Brazilian agribusiness and the maize stands out as the second activity in this scenario. Maize is cultivated in all agricultural areas in Brazil, with different levels of technology and investment, being grown in two distinct crop seasons. The first (summer) crop season occurs during the rainy period. As to the second season, also known as dryland crop, the planting is done from January until the middle of April. Both crop seasons totalized a grain yield of approximately 5.7 kilograms per hectare in the 2018/19 season (Acompanhamento da Safra Brasileira [de] Grãos, 2019).

Taking into account that the maize demands great volume of water, the main reason for the high yield variability presented by this crop is the water deficit, caused by the instabilities of the rainfall regime (Souza et al., 2015).

The seed size can also influence the initial development of seedlings. Researches have already identified a relation of seed size and shape with crop yield (Kara, 2011; Westoby, 1996; Pádua et al., 2010). Additionally, the seed quality involves many genetic, sanitary, physiological and physical aspects, which, in an integrated manner, ensure the usage potential of seeds (Carvalho \& Nakagawa, 2000).

According to Westoby (1996), seedlings from larger seed species are capable of surviving hazards such as shading and drought conditions, physical damages, and the presence of weeds. This occurs due to a "reserve effect", through which the initial development and growth of larger seed species have a greater percentage of reserves available to help with breathing or to repair damages.

There is a clear need for development and use of genotypes that are tolerant to water stress in maize crops, as an efficient tool to increase the productivity and reduce the production risks in areas and periods subject to that limiting factor. In view of that, the objective of this research was to characterize the influence of the seed size on maize seedling traits, under contrasting conditions of water availability.

\section{Material and Methods}

The research was conducted in the Central Seed Laboratory, located in the Agriculture Department of the Federal University of Lavras (UFLA), in the municipality of Lavras, MG. Experimental design was used, in a $3 \times 2 \times 3$ factorial arrangement, consisting of three genotypes, two water availability conditions and three different sieve sizes. The design was completely randomized, with four replications.

In this research, the selected materials were obtained from the maize improvement 
programs of the Federal University of Lavras. Two contrasting lines were chosen, being the L91 tolerant (T) and the L57 non-tolerant (NT) in regard to water restriction; in addition to the $\mathrm{F}_{2}$ resulting from the cross between those two lines (Abreu et al., 2018).

First, the seeds were separated with the use of oblong-hole sieves and after that, they were classified in round-hole sieves. The seeds retained on the sieves (sizes 22, 20 and 18/64") were selected for use. Subsequently, they were stored in a cold chamber at $10^{\circ} \mathrm{C}$, until the time when the analyses would be conducted.

The seeds were exposed to two conditions, with and without water deficit, in four replications with 25 seeds. They were sown in plastic trays ( $20 \mathrm{~cm} \times 22 \mathrm{~cm} \times 12 \mathrm{~cm}$ ), with washed, dried and sieved sand being used as substrate. In order to determine the water stress condition, the water retention capacity of the substrate was adjusted to $10 \%$; for the control condition, this adjustment was of $70 \%$. For germination, the trays were placed into a growth chamber at $25^{\circ} \mathrm{C}$. Water was replenished daily, based on the initial weight of each tray.

All selected seeds (lines and $\mathrm{F}_{2}$ ) were evaluated in regard to the seedling characteristics under adverse conditions (with and without water stress) and the physiological quality of the seeds. After 7 days, the seedlings were removed from the substrate and washed in running water.

Emergence evaluation was carried out, considering the percentage of seedlings emerged on the seventh day after sowing. The emergence speed (ES) was obtained by assessing the number of seedlings emerged per day. Both tests were conducted together. The ES was calculated through the formula proposed by Edmond and Drapala (1958).

$$
\mathrm{ES}=\frac{\left(E_{1} N_{1}\right)+\left(E_{2} N_{2}\right)+\cdots+\left(E_{n} N_{n}\right)}{E_{1}+E_{2}+\cdots+E_{n}}
$$

Where:

$\mathrm{ES}=$ emergence speed (in days);

$E_{1}, E_{2}, E_{n}=$ number of normal plants emerged in the everyday counts;

$\mathrm{N}_{1}, \mathrm{~N}_{2}, \mathrm{~N}_{\mathrm{n}}=$ number of days in relation to sowing. The number of roots and the length of shoot and root were assessed through the average value of twenty seedlings, obtained from the emergence test of the water treatments. Shoot and root were measured with the use of a graduated ruler, being both measures expressed in centimeters. Afterwards, the number of seminal roots was counted.

Twenty seedlings were separated and weighed on a scale in order to obtain their fresh weight. Subsequently, these materials were stored in ovens at $65{ }^{\circ} \mathrm{C}$, during three days, and then weighed again to obtain shoot and root dry weight, both expressed in grams.

The statistical analyses were carried out with the use of Sisvar ${ }^{\circledR}$ software (Ferreira, 2011). The mean values were compared through Tukey's test at 5\% probability, and the analysis of variance (ANOVA) was conducted, also at 5\% probability. 


\section{Results and Discussions}

The summary of the analysis of variance for number of roots (NR), root length (RL), shoot length (SL), root weight (RW), shoot weight (SW), root dry weight (RDW), shoot dry weight (SDW) and emergence speed (ES) is presented in Table 1.

It can be observed that the genotype factor presented significant differences in almost all characteristics evaluated, except for RDW. The water condition (environment) factor did not produce significant differences only in NR. The sieve size factor had significant impact on NR, RW, SW, SDW and ES. There was significant interaction between the genotype and sieve factors for NR, RW, SW and RDW. The interaction between genotype and environment was not significant only for NR and ES.

The interactions among sieve and environment and genotype, as well as between sieve and environment, did not produce significant impact in regard to any characteristic evaluated.

In the interaction between genotype and sieve, with regard to the number of roots (Table 2), it is possible to observe that the L57 was superior in relation to the other genotypes in almost all sieves (with exception of size 20 where the $\mathrm{F}_{2}$ and L57 were statistically identical) and the L91 was inferior in respect to the same variable. In relation to L91, all sieves presented values that did not differ significantly. As to the L57 and $\mathrm{F}_{2}$, the sieve that stood out was the size

Table 1. Summary of the analysis of variance (ANOVA) of data obtained for the following characteristics: number of roots (NR), root length (RL), shoot length (SL), root weight (RW), shoot weight (SW), root dry weight (RDW), shoot dry weight (SDW) and emergence speed (ES).

\begin{tabular}{|c|c|c|c|c|c|c|c|c|c|}
\hline Source of Variance & DF & NR & RL & SL & RW & SW & RDW & SDW & ES \\
\hline Genotype & 2 & $55.3929^{*}$ & $30.9622 *$ & $27.1076^{*}$ & $57.1400^{*}$ & $28.8088^{*}$ & 0.1284 & $0.2433^{*}$ & $0.1126^{*}$ \\
\hline Water condition (Environment) & 1 & 0.1701 & $44.3368^{*}$ & $83.2050^{*}$ & $32.8050^{*}$ & $69.6200^{*}$ & $30.7328^{*}$ & $0.6747^{*}$ & $0.0435^{*}$ \\
\hline Sieve & 2 & $2.8904 *$ & 1.4093 & 2.4568 & $20.7204 *$ & $13.8293 *$ & 0.7305 & $0.1160^{*}$ & $0.0366^{*}$ \\
\hline Genotype $x$ Sieve & 4 & $1.7558^{*}$ & 0.5576 & 1.3968 & $9.0441 *$ & $3.1263^{*}$ & $1.5555^{*}$ & 0.0166 & 0.0186 \\
\hline Genotype x Environment & 2 & 0.0068 & $9.7738^{*}$ & $2.4837^{*}$ & $16.1716^{*}$ & $2.5316^{*}$ & $1.4479^{*}$ & $0.0646^{*}$ & 0.0121 \\
\hline Sieve $x$ Environment & 2 & 0.0668 & 3.2518 & 1.1754 & 4.3829 & 0.1662 & 0.8964 & 0.0080 & 0.0041 \\
\hline Genotype $x$ sieve $x$ Environment & 4 & 0.0809 & 0.8938 & 0.6541 & 5.0633 & 0.2854 & 0.4708 & 0.0048 & 0.0096 \\
\hline Error & 54 & 0.0738 & 1.9915 & 0.6172 & 2.2013 & 0.3663 & 0.3953 & 0.0086 & 0.0086 \\
\hline CV (\%) & & 5.49 & 11.27 & 8.17 & 20.95 & 9.57 & 35.60 & 18.87 & 1.61 \\
\hline
\end{tabular}

* Significant at 5\% level, as per Tukey's test. 


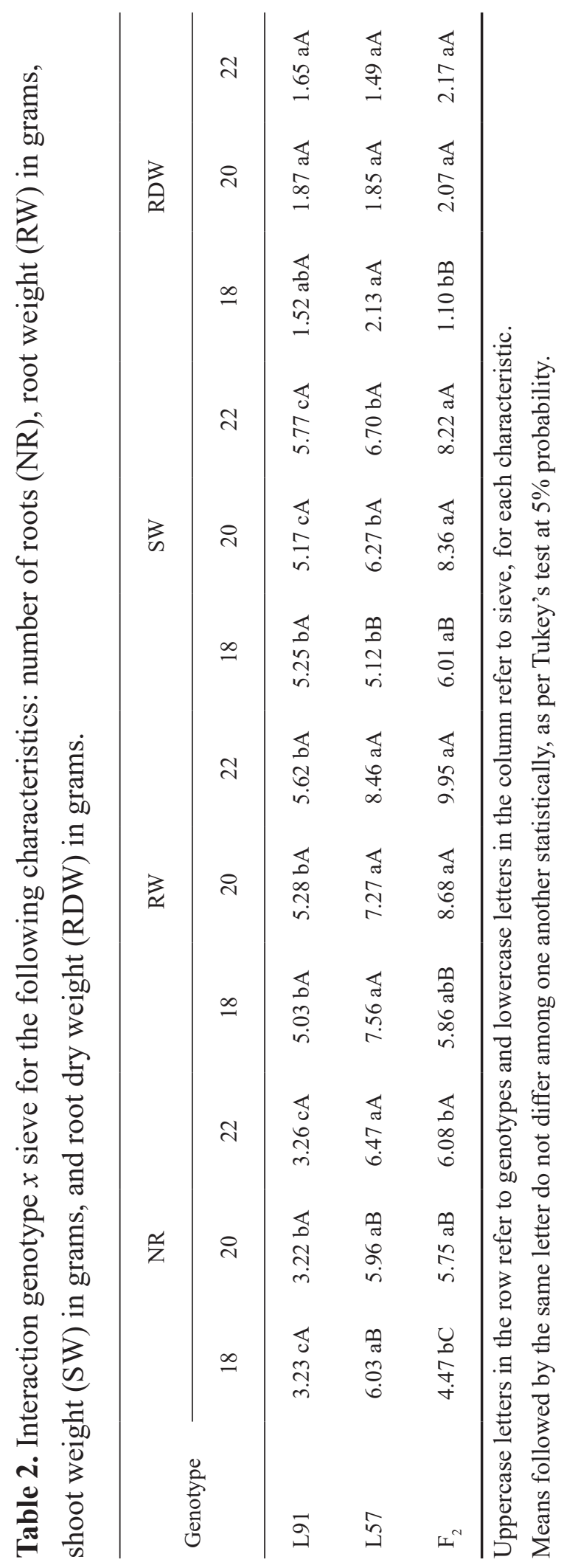


22 , with higher values in relation to the others.

In general, in the interaction between genotype and environment, with regard to root length, the genotype L57 also attained a result superior to the L91 (Table 3). The treatments with and without water restriction ( $10 \%$ and $70 \%$, respectively) were statistically identical in relation to almost all genotypes, with exception of $\mathrm{F}_{2}$, which was superior in the $70 \%$ water condition, when compared with the $10 \%$ condition. When the interaction between genotype and environment was evaluated as to shoot length, at water condition of $10 \%$, the L57 and $\mathrm{F}_{2}$ were statistically identical and superior to the genotype L91. At water condition of $70 \%$, the $\mathrm{F}_{2}$ was superior in relation to both lines (which were statistically identical).

The root weight characteristic presented interaction between the genotype and sieve factors, in which the sieve sizes 22 and 20 were superior to size 18 for genotype $F_{2}$ (Table 1 ). The $\mathrm{L} 57$ and $\mathrm{F}_{2}$ stood out in respect to sieves (Table 2). With regard to the interaction between genotype and environment, in both water conditions ( $70 \%$ and $10 \%$ ), the $\mathrm{F}_{2}$ and L57 were superior to the genotype L91. For L91 and L57, the 10\% water condition was superior to the $70 \%$, but the cross between them $\left(\mathrm{F}_{2}\right)$ obtained results that did not significantly differ among one another (Table 3 ).

When analyzing the interactions that were significant in regard to shoot weight, it was possible to observe that the genotype $\mathrm{F}_{2}$ was superior considering all sieve sizes. With regard to the genotypes in general, the sieve sizes 22 and
20 were identical, but superior if compared with size 18, with exception of the L91, for which all materials obtained the same result.

In respect to the interaction between genotype and environment, at both field capacity conditions ( $70 \%$ and $10 \%$ ), the genotype $\mathrm{F}_{2}$ was superior and the L91 had the lowest result. For all materials analyzed, the environment with no water restriction $(70 \%)$ was superior to the $10 \%$ condition.

High vigor seeds present higher speed in the metabolic processes, which favors a faster and more uniform emission of the primary root in the germination process and higher growth rate, thus producing seedlings with larger initial size (Schuch et al., 1999; Munizzi et al., 2010). Therefore, as it could be observed in this work, the greater shoot development presents a relation with the total weight, being possible to infer that when such characteristics stand out, the seedlings are more tolerant to water restriction.

It is also important to highlight that the seed classification according to its size and mass can represent a strategy for the increment of productivity, since the seed size affects germination, plant vigor and grain production. Additionally, seeds with uniform size increase the precision of mechanical sowing (Krzyzanowski et al., 1991). The explanation that has been commonly presented for the potential influence of seed size on seedling vigor, and subsequent plant behavior, is that the large seeds have a greater amount of reserve tissue, thus being capable of originating better nourished seedlings 


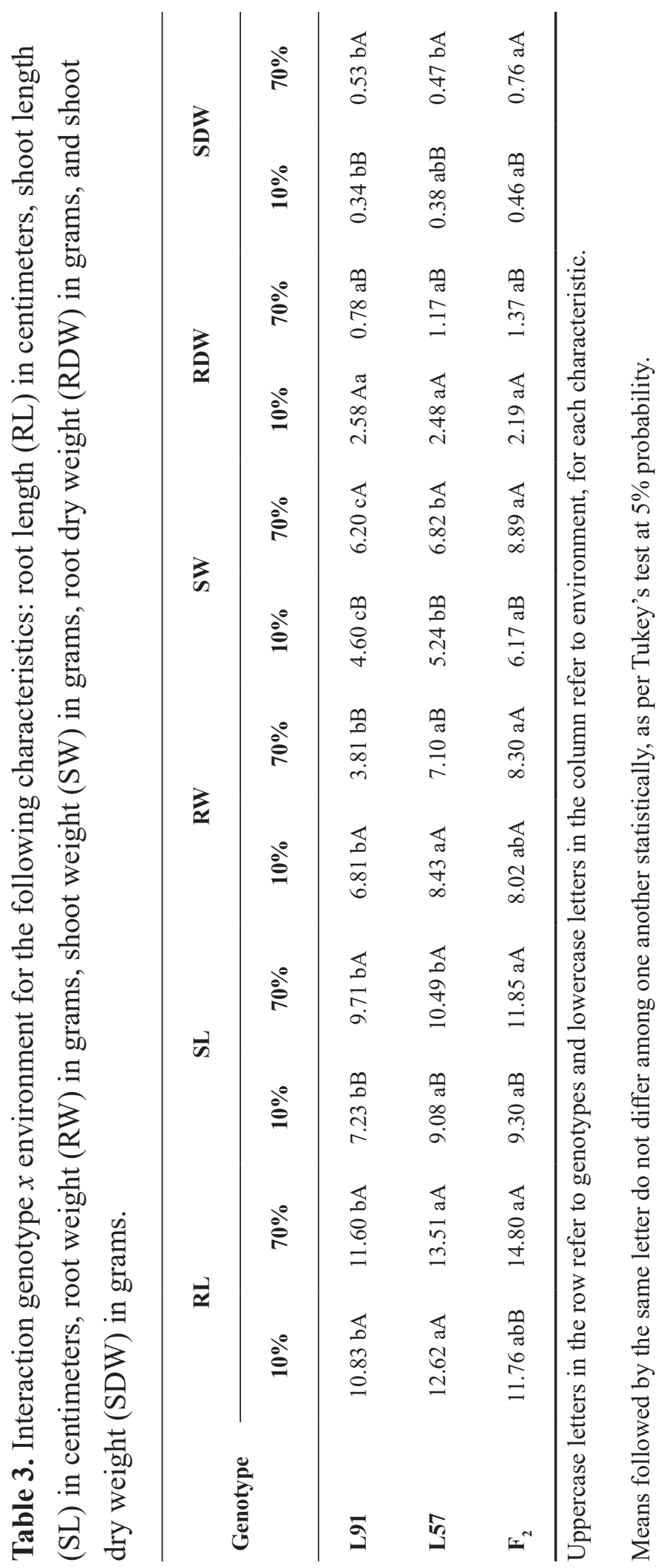


(Carvalho \& Nakagawa, 2000). Consequently, larger seedlings, as it could be observed in this work, can generate more vigorous plants in the field, highlighting the importance of their classification per size, which shall result in better developed plants, even when they are exposed to water restriction conditions.

In relation to root dry weight, there was interaction between genotype and sieve (Table 2). The $L 57$ was superior to $F_{2}$ and $L 91$, with the latter being superior to $\mathrm{F} 2$ in sieve size 18 .

As to the genotypes, they were considered statistically similar in relation to the sieves, with exception of $\mathrm{F}_{2}$, for which the sieve sizes 22 and 20 were superior to the size 18. In Table 3, referent to the interaction between genotype and environment, the genotypes were statistically identical to each other in both conditions $(10 \%$ and $70 \%)$. The environment with water restriction (10\%) was superior if compared with the environment with no restriction (70\%).

With regard to shoot dry weight, in the interaction between genotype and environment, the $\mathrm{F}_{2}$ was superior in the two water conditions $(10 \%$ and $70 \%)$. For all genotypes, the condition of no water stress presents the highest values for dry weight.

The effects of the seed size characteristic have been studied by many authors, considering the most different performance components of the seed and the plant originated from it (Kara, 2011; Westoby, 1996; Pádua et al., 2010).

Cameron et al. (1962) verified that the differences in the behavior of large and small seeds of sweet maize were intensified under adverse conditions of the environment, with advantage for the larger ones. The small seeds produced lower percentage of seedling emergence and less productive plants. However, under favorable climate conditions, these differences were not manifested.

Several studies have demonstrated the influence of the size and shape of seeds on early stages, yield components and final yield of crops (Kara, 2011; Shoushtar, 2011). Sangoi et al. (2004), when testing the effect of four sowing depths $(0.025 ; 0.050 ; 0.075$ and $0.10 \mathrm{~m})$ and two seed sizes (thousand grain weight of $451.2 \mathrm{~g}$ and $245.2 \mathrm{~g}$ ) on maize crop behavior, verified that larger seeds favored the attainment of higher emergence speeds, with taller plants with greater phytomass accumulation at harvest, due to the greater nutrient concentration in the grain. On the other hand, Muchena and Gnocnn (1977), using three strains of maize (popcorn, R151 pure line and Ay499 pure line) and three seed sizes (small, medium and large), observed that the smaller seeds tend to present higher emergence speed in maize crop. However, in this work, the emergence speed was not significant for the three genetic materials tested, as shown in the analysis of variance chart (Table 1).

\section{Conclusions}

The seed size directly influences the development of maize seedlings, regardless of 
being line or hybrid, when they are submitted to water restriction. In this case, the larger-size sieves (22 and 20) were superior when compared with the sieve size 18 .

When it is necessary to carry out sowing under water restriction conditions, the prior classification of the seeds is required, regardless of whether they are lines or hybrids.

In the early stages, L57 was more tolerant to water restriction, when compared with L91.

The genotype that most stood out, in relation to various characteristics, was the $\mathrm{F}_{2}$.

\section{Acknowledgments}

To the National Council for Scientific and Technological Development (CNPq), Coordination for the Improvement of Higher Education Personnel (CAPES), and Minas Gerais Research Funding Foundation (Fapemig), for the granting of scholarships.

\section{References}

ABREU, V. M.; PINHO, E. V. R. V.; MENDESRESENDE, M. P.; BALESTRE, M.; LIMA, A. C.; SANTOS, H. O.; PINHO, R. G. V. Combining ability and heterosis of maize genotypes under water stress during seed germination and seedling emergence. Crop Science, v. 59, n. 1, p. 33-43, 2018. DOI: 10.2135/cropsci2018.03.0161.

\section{ACOMPANHAMENTO DA SAFRA} BRASILEIRA [DE] GRÃOS: safra 2018/19: décimo segundo levantamento. Brasília, DF: Conab, 2019. Disponível em: <https://www. conab.gov.br/info-agro/safras/graos>. Acesso em: 8 dez. 2019.

CAMERON, J. W.; VAN MOREN, A.; COLE JR., D. A. Seed size in relation to plant growth and time of ear maturity of hybrid sweet corn in a winter planting area. Proceedings of the American Society for Horticultural Science, v. 80, p. 481-487, 1962.

CARVALHO, N. M.; NAKAGAWA, J. Sementes: ciência, tecnologia e produção. 4 . ed. Jaboticabal: FUNEP, 2000. 588 p.

EDMOND, J. B.; DRAPALA, W. J. The effects of temperature, sand and soil, and acetone on germination of okra seed. Proceedings of the American Society for horticultural Science, v. 71, n. 1, p. 428-434, 1958.

FERREIRA, D. F. Sisvar: a computer statistical analysis system. Ciência e Agrotecnologia, v. 35, n. 6, p. 1039-1042, 2011. DOI: 10.1590/ S1413-70542011000600001.

KARA, B. Effect of seed size and shape on grain yield and some ear characteristics of maize. Research on Crops, v. 12, n. 3, p. 680685, 2011.

KRZYZANOWSKI, F. C.; FRANÇA-NETO, J. B.; COSTA, N. P. Efeito da classificação de sementes de soja por tamanho sobre sua qualidade e a precisão de semeadura. Revista Brasileira de Sementes, v. 13, n. 1, p. 5968, 1991. DOI: 10.17801/0101-3122/rbs. v13n1p59-68.

MUCHENA, S. C.; GNOCNN, C. O. Effects 
of seed size on germination of corn (Zea mays) under simulated water stress conditions. Canadian Journal of Plant Science, v. 57, n. 3, p. 921-923, 1977. DOI: 10.4141/cjps77-131.

MUNIZZI, A.; BRACCINI, A. L.; RANGEL, M. A. S.; SCAPIM, C. A.; ALBRECHT, L. P. Qualidade de sementes de quatro cultivares de soja, colhidas em dois locais no estado de Mato Grosso do Sul. Revista Brasileira de Sementes, v. 32 , n. 1, p. 176-185, 2010. DOI: 10.1590/ S0101-31222010000100020.

PÁDUA, G. P. de; ZITO, R. K.; ARANTES, N. E.; FRANÇA NETO, J. B. Influência do tamanho da semente na qualidade fisiológica e na produtividade da cultura da soja. Revista Brasileira de Sementes, v. 32, n. 3, p. 9-16, 2010.

RAO, D. E.; CHAITANYA, K. V. Photosynthesis and antioxidative defense mechanisms in deciphering drought stress tolerance of crop plants. Biologia Plantarum, v. 60, n. 2, p. 201218, 2016. DOI: 10.1007/s10535-016-0584-8.

SANGOI, L.; ALMEIDA, M. L. de; HORN, D.; BIANCHET, P.; GRACIETTI, M. A.; SCHMITT, A.; SCHWEITZER, C. Tamanho de semente, profundidade de semeadura e crescimento inicial do milho em duas épocas de semeadura. Revista Brasileira de Milho e Sorgo, v. 3, n. 3, p. 370380, 2004. DOI: 10.18512/1980-6477/rbms. v3n3p370-380.

SCHUCH, L. O. B.; NEDEL, J. L.; ASSIS, F. N. Crescimento em laboratório de plântulas de aveia-preta (Avena strigosa Schreb.) em função do vigor das sementes. Revista Brasileira de Sementes, v. 21, n. 1, p. 229-234, 1999.

SHOUSHTAR, I. Response of the morphologic characteristics of s.c704 maize affected by the source and seed size in Khuzestan. Australian Journal of Basic and Applied Sciences, v. 5, n. 11, p. 369-374, 2011.

SOUZA, L. C.; MELO, N. C.; SIQUEIRA, J. A. M.; OLIVEIRA NETO, C. F. Comportamento bioquímico no milho submetido ao déficit hídrico e a diferentes concentrações de silício. Revista Agrarian, v. 8, n. 29, p. 260-267, 2015.

WESTOBY, M.; LEISHMAN, M.; LORD, J. Comparative ecology of seed size and dispersal. Philosophical Transactions of the Royal Society of London. Series B: Biological Sciences, v. 351, n. 1345, p. 1309-1318, 1996. DOI: $10.1098 /$ rstb.1996.0114. 